\title{
VERSITA
}

Ekológia (Bratislava)

Vol. 32, No. 3, p. 283-289, 2013

doi:10.2478/eko-2013-0025

\section{THE IMPORTANCE OF RURAL PARKS FOR THE OCCURRENCE OF THE ROOK Corvus frugilegus IN THE EASTERN PART OF THE LUBLIN REGION (E POLAND) - ECOLOGICAL AND SOCIAL FACTORS}

\author{
IGNACY KITOWSKI
}

State School of Higher Education in Chelm, Pocztowa 54, PL 22-100 Chelm, Poland; e-mail: ignacyk@autograf.pl

\begin{abstract}
Kitowski I.: The importance of rural parks for the occurrence of the Rook Corvus frugilegus in the eastern part of the Lublin region (E Poland) - ecological and social factors. Ekológia (Bratislava), Vol. 32, No. 3, p. 283-298, 2013.

This study deals with the population size and the distribution of breeding colonies of the rook in rural parks in the eastern part of the Lublin region (Eastern Poland). Large parks with a large number of tree species were appropriate sites for larger rookeries. Small, degraded parks, with few species of trees, were used by smaller rookeries, which showed tendencies to disappear more quickly. Small colonies were irrevocably abandoned if disturbed by man, whereas large ones had a very high reoccupation potential, even after a few years. Unfortunately, ownership changes concerning rural parks in Eastern Poland may endanger the rookeries located there.
\end{abstract}

Key words: rook, colonies, rural parks, farmland.

\section{Introduction}

A majority of the rural parks that survive to this day in Poland date back to the 19th century. Cared for and planted with new trees by their owners in many cases, they now constitute clusters of valuable dendroflora and banks of its genes (Truchan, Sobisz, 2006; Kułak, Sender, 2011). Rural parks are also an important refuge for birds in farmland. Still, present knowledge concerning the birds breeding there, as opposed to other types of farmland woodlots, is insufficient and needs urgent attention (Tryjanowski et al., 2009). Older data indicate that 84 species of bird were reported in the rural parks of Poland (from 21 to 55 species, depending on the size of the park) (Tryjanowski et al., 2009). In the Lublin region (Eastern Poland), about 690 manor and palace parks have been found, one-third of which no longer exist. Those that survive have, in many cases, been dendrologically and architecturally transformed. Fijałkowski and Kseniak (1983) report that the overall tree stand in the parks of the Lublin region dwindled by $80 \%$ compared to the period preceding World War II.

Rural parks are also important places where rooks Corvus frugilegus set up their colonies in Poland (Hordowski, 2004; Orłowski, Czapulak, 2007; Tobółka et al., 2011). According to Taczanowski (1882), until as late as the mid-19th century rooks did not nest in what is now 
the Lublin region. It is assumed that this species settled in the region in the late 1880 s, and towards the end of the $19^{\text {th }}$ century it was already recognised as a common species (Biadun, Wojciak, 2005). Currently, rookeries have been disappearing from Poland, including the Lublin region, and even large ones with several hundred nests are being deserted (Biaduń, Wojciak, 2005; Neubauer et al., 2011). On the other hand, the ecological and economic importance of the rook in seed dispersal processes as well as its significance to pest control is recognised (Gromadzka, 1980; Czarnecka, Kitowski, 2010; Czarnecka, Kitowski, 2013). The aim of this article is to present the results of inspections of nearly 240 rural parks located in the east of the Lublin region in the context of the role they play in determining the occurrence of the rook.

\section{Methods}

The study was carried out in the eastern part of the Lublin region (Fig. 1) during 2009-2011. Field inspections were held between 7 and 28 April each year. A total of 239 rural parks were inspected, located in the following districts: Biała Podlaska, Radzyń Podlaski, Parczew, Włodawa, Łęczna, Chełm, Krasnystaw, Zamość, Hrubieszów and Tomaszów Lubelski. Apart from these, the study covered rural parks in the eastern part of Lubartów district (communes: Lubartów, Serniki, Ostrów Lubelski, Uścimów, Niedźwiada, Ostrówek, Firlej, Kock). In total, it covered an area of $14,914.49 \mathrm{~km}^{2}$ inhabited by about 300,000 people.

Only those cases were analysed where a colony was located in a park and consisted of at least one rook nest, regardless of the current state of the park (i.e. the degree of transformation). The following variables were used in describing the colonies: colony size (the total number of nests in the colony), the average number of nests per tree and the maximum number of nests per tree in the colony. Parks were described using the following variables: park size in hectares, the number of trees growing there and the number of tree species taken from Fijałkowski and Kseniak (1983) or collected directly in the field studies. For 38 parks, counts from 2011 were available, and in the case of the 21 parks for which results were available from both 2010 and 2011, the factors influencing the size of colonies were assessed by correlating the 2011 colony size variables with variables characterizing parks. The area of the park was measured using the ArcView program (version 3.2) and expressed in hectares (ha) (ArcView, 1996 )

\section{Results}

In the 239 parks inspected within the study area in 2010-2011, 41 active rookeries were found and 11 colonies where nests of the studied species were unoccupied, which means that the birds used $17.2 \%$ of parks. In many cases, birds nesting in parks used anthropogenic food resources since in 21 cases $(51.2 \%)$ their colonies were located in the immediate vicinity of human settlements (such as residential blocks), in 8 cases (19.5\%) rookeries neighboured on hospitals or social welfare centres and in 7 cases $(17.1 \%)$ they were situated near schools. Three colonies (7.3\%) were located in the immediate proximity of the infrastructure of large farms. Two rookeries $(4.9 \%)$ were situated in parks located in the centres (market squares) of settlements that used to be towns.

In 2011, active colonies ( $n=38$ ) with 9948 nests were inspected in the studied parks, with a median size of 231.5 nests and an average of 248.6 nests per colony (range: 1-742 nests). The median number of nests in colonies newly abandoned by rooks $(n=11)$ was 11.0 nests, mean: 17.8 nests (range: 3-72 nests). Differences in the median number of nests between active and abandoned rookeries were significant: (Mann-Whitney $U$ test: $Z=3.96, n_{1}=38, n_{2}=11, p<$ $0.00001)$. 


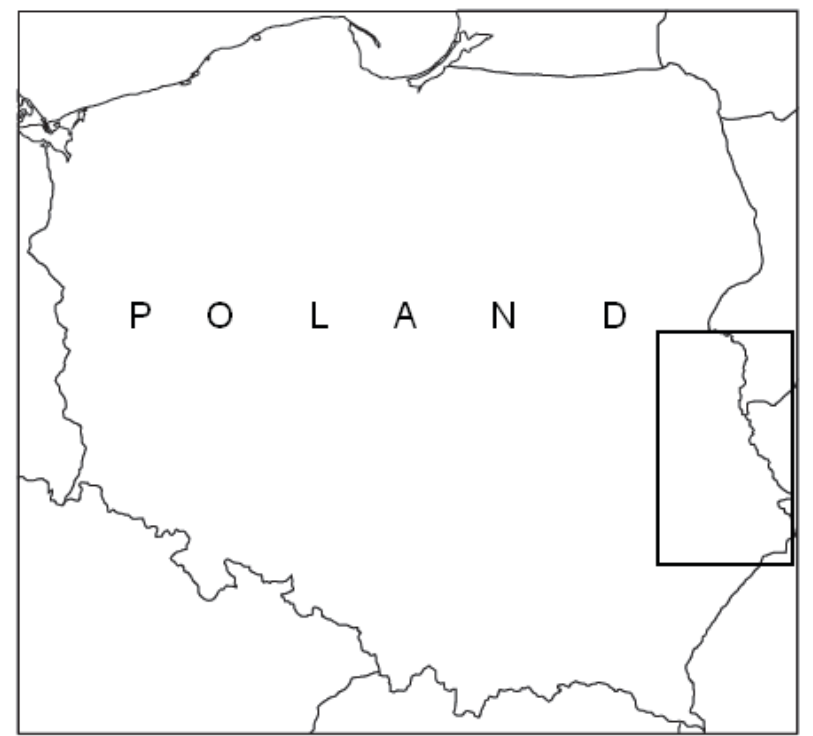

Fig.1. Study area where colonies of rook Corvus frugilegus were surveyed.

Of the active colonies inspected, as many as 25 (61.0\%) consisted of more than 100 nests. On average, the studied rooks located from 1.0 to 11.6 nests on one tree, depending on the colony. Birds in the inspected rookeries occupied an average of $50.3 \pm 39.4$ trees, median: 48.5 trees (range: 1-158 trees). The average number of nests located on one tree was 4.94 . The maximum number of nests located on one tree in the active colonies inspected varied from 1 to 57.

It was demonstrated that with the increase in the area of parks, the size of rookeries located there grew as well (Spearman's $r=0.385, n=38, p=0.027$ ). The median size of parks where active colonies were located (median $=4.0$ ha, range: $0.4-15$ ha) was greater than that of parks in which colonies with abandoned nests were found (median $=3.0$ ha, range: 0.5 $11.0 \mathrm{ha}$ ), but the differences were not significant (Mann-Whitney $\mathrm{U}$ test: $\mathrm{Z}=0.803, \mathrm{n}_{1}=38$, $\left.\mathrm{n}_{2}=11, \mathrm{p}<0.420\right)$. A greater area of parks favoured a greater number of trees on which birds set up the nests of active colonies $(r=0.387, n=38, p=0.016)$. Park's areas explain as much as $\left(\mathrm{R}^{2}=15.0 \%\right)$ of variance in the number of trees occupied by rooks for nesting in colonies.

An important variable characterising the parks was the number of tree species found there. A significant correlation was found between the number of tree species occurring in parks where rookeries were located and the size of those colonies $(r=0.584, n=38, p=$ $0.0001)$ as well as the number of trees occupied by rooks $(r=0.614, n=38, p=0.00004)$. The number of tree species found in parks where rookeries were located allowed to explain as much as $\left(R^{2}=34.0 \%\right)$ of variance in colony size and as much as $\left(R^{2}=37.7 \%\right)$ of variance in the number of trees used by the studied birds for nesting.

The median number of tree species reported in the parks where occupied rookeries were found (median $=18.0$, range: 9-47 species) was higher compared to the 11 parks where aban- 
doned colonies were reported (median $=14.0$, range: 10.0-22.0 species). However, the differences were not statistically significant (Mann-Whitney $\mathrm{U}$ test: $Z=1.35, n_{1}=38, n_{2}=11$, $p=0.179$ ). In addition, stand density (the number of trees per one hectare of park area) was higher in the parks where occupied rookeries were found (median $=72.0$, range: $12.5-302$ trees per hectare) compared to the parks in which abandoned colonies were reported (median $=60.0$, range: 2.2-208.0 trees per hectare). However, the differences were not significant (Mann-Whitney U test: $Z=0.328, n_{1}=38, n_{2}=11, p=0.746$ ).

For $21(51.2 \%)$ out of 41 active rookeries, data were available concerning their size in 2010 and 2011. For these colonies, median colony size in 2010 was 341 nests (range: 79-689 nests), and by 2011 median colony size for the same rookeries decreased to 271 nests (range: 36-742 nests). This decrease in the median number of nests was statistically significant (Wilcoxon test: $T=57.5, n=21, p=0.044$ ). Sometimes large breeding colonies function in parks that lie close to each other, a good example being the pairs of rookeries in parks neighbouring on one another in the villages of Kozic Górny and Kozic Dolny as well as Siostrzytów and Łysołaje). Sometimes a rookery that has functioned for many years moves not very far away (less than 100 metres ) but beyond the boundaries of the park: I found such cases in Werbkowice ( in 2010) and Kijany (in 2011).

\section{Disturbances of reproduction}

The inspections carried out allowed to identify the factors threatening the 41 active rookeries studied. In as many as 13 of them $(31.7 \%)$ it happened that trees with rook nests located on them were felled. In five colonies (12.2\%) (Chojno Nowe, Kozice Górne, Kozice Dolne, Trzeszczany, Wola Uhruska), pyrotechnics were intentionally used in order to drive birds away during their period of reproduction. In two rookeries (4.9\%), cases of birds getting intentionally killed with guns were reported (sites: Chojno Nowe, Rejowiec Osada). Destroying nests or knocking them off trees (by climbers, using fire hoses or by trimming branches with nests on them) took place in four sites (7.3\%) (Chojno Nowe, Rejowiec Osada, Tarnogóra, Sitno). In two colonies (Eabuńki Pierwsze, Krynice), due to the location of nests in the immediate proximity of a busy road, cases of collisions with vehicles were reported. One rookery (Rejowiec Osada) was intentionally poisoned, and as many as 15 rookeries (36.6\%) were subject to various kinds of penetration: digging up in search of worms for fishing, rubbish dumping, making bonfires, etc. Apart from the already mentioned 11 newly abandoned colonies, in 23 out of 238 inspected parks (9.7\%), interviews with the local people revealed the disappearance of large colonies (>100 nests ) over the last 30 years, which, in a vast majority of cases, was due to regular persecution by humans.

Rooks from large colonies located in parks had a high potential for reoccupying the parks from which they were driven out by humans. A proof of this is the rookeries in Rejowiec Osada and Chojno Nowe, subject to culling and unoccupied for 2-3 years; when persecutions ceased, birds reoccupied the rookeries. In the case of the latter colony, an important factor in the reoccupation was the functioning of another large colony in a pine grove about $1 \mathrm{~km}$ away. A case that deserves special attention is the disappearance of the rookery in Strzelce, also situated in a rural park. During an inspection in 2012 no nest was found there, whereas back in 2007 the park had a functioning active rookery with 69 nests. 


\section{Discussion}

The surveys carried out in the rural parks of the eastern part of the Lublin region confirms that the process observed all over Poland (Neubauer et al., 2011) concerns farmland as well, although its intensity appears to vary. Hordowski (2009), who surveyed colonies in the Przemyśl region, reports that from 1987 to 2006 the population decreased by $10 \%$ there, but in farmland the decrease was more sharp. These results correspond with the observation at the Gen. Dezydery Chłapowski Landscape Park (the Wielkopolska region) (Kujawa, Klajber, 2005). The surveys carried out there in 2000-2001 showed that rook population size decreased by approximately 40\% compared with the figure for 1971-1974.

Unfortunately, there are no published data on the size of rook population associated with rural parks in the east of the Lublin region. Only Profus et al. (1992) report that the colony located in the rural park in the village of Krynice (Tomaszów Lubelski district) consisted of 450-500 nests in the late 1980s while the 2010 survey revealed the presence of a mere 189 nests, which shows a twofold decrease in the size of the rookery over a period of more than 20 years.

Existing studies concerning the territory of Poland show that rooks in Western Poland tend to form smaller colonies compared to those in Eastern Poland (Hordowski, 2004; Kasprzykowski, 2005; Orłowski, Czapulak, 2007; Tobółka et al., 2011; Jakubiec 2005). The rural park colonies we studied were large colonies and comprised an average of 248.6 nests. Counts from the east of the Lublin region correspond with surveys from other parts of Poland, particularly with those from SE Poland. Hordowski (2004) reports the following figures for the 18 rural parks found in Jarosław and Przemyśl districts (SE Poland): colony size: 2-468 nests; mean: 209.7 nests; median number of nests: 161.0.

Kamecki (2004) reports on 10 rookeries of Przeworsk district, comprising an average of 203.2 nests. Among those, colonies in rural parks comprised an average of 217.0 nests. On the other hand, however, in 1999, rookeries located in rural parks in the vicinity of Rzeszów (SE Poland) (Kawa, Pelc, 2001) comprised an average of 102.1 nests, the median number of nests being 38.5 (range: 7-500 nests). The colonies in the rural parks of Western Poland ( $n$ =6) surveyed by Pietrowiak (2011) had an average of 124.7 nests in 2010, with the median value of 126 nests (range: 17-268 nests).

A clear symptom of decrease in the number of rookeries in Poland is the desertion of active colonies. It has been observed (Orłowski, Czapulak, 2007; Tobółka et al., 2011) that the smaller the number of nests making up a colony, the higher the likelihood of the colony being deserted by rooks. Abandoned breeding colonies in rural parks in the eastern part of the Lublin region were, on average, 14.0 times smaller than the occupied ones. In Lower Silesia, active rookeries were six times larger than the unoccupied ones (median values: 99.0 nests vs. 16.0 nests) (Orłowski, Czapulak, 2007). Grzybek (2004) also reports that abandoned rookeries in SE Poland grouped a smaller number of nests, but larger rookeries showed greater reoccupation potential. It is possible that old nests remaining on trees play a significant role in this process by signalling the quality of the habitat.

The number of rook nests located on one tree reported during the survey in the eastern part of the Lublin region was between 1 and 57. This result is very similar to that obtained in 
the west of Poland, where the number of trees located on a single tree was 1-62 for Leszno Province (Kuźniak et al., 2005). However, subsequent data from the same area mention a maximum of 35 nests found on one tree (Tobółka et al., 2011), while Pietrowiak (2011) reports the maximum number of nests found on a single tree to be 52. Still, data from a different part of Wielkopolska (the vicinity of Ostrów Wielkopolski) mention 29 as the maximum number of nests found on one tree (Dolata, 2005). Reporting on the figures for Przeworsk district, Kamecki (2004) informs that, in the colonies surveyed there, an average of 3.9 nests were located on one tree (1-42 nests) and the maximum number of nests on a tree was 75 . Data collected in the Lublin region as well as those provided by other authors show that there is a certain optimum number of nests to be located on one tree. Probably, an increase in the number of nests may affect breeding efficiency.

Researchers from different parts of Poland (Kawa, Pelc, 2003; Kuźniak et al., 2005; Tobółka et al., 2011) show that disturbing birds is common practice and appears to determine, to some degree, the size and distribution of colonies. In some parts of Poland, it is the main factor shaping population size in colonies. In Pleszew district (Wielkopolska, W Poland) the decrease in the number of rooks in 2005-2007 by as much as 35\% resulted from the persecution of birds, e.g. felling trees with nests and shooting (Żurawlew, 2007). Persecution was the main factor influencing changes in the population size and, above all, in the distribution of the rook (Pietrowiak, 2011). Recently, ownership changes have constituted a new factor strongly favouring the persecution of colonies. In many cases, village schools are closed down due to demographic reasons. Together with the parks within which they lie, they are currently being sold out by local authorities to private owners. New owners very often scare birds during renovation works. The material collected shows that a factor significant to the occurrence of rooks was the fact that, in many cases, there were institutions functioning in rural parks that provided rooks with a certain amount of anthropogenic food. That food was either leftovers from school and dormitory canteens, hospitals or nursing homes or feed prepared for animals. The disappearance of these sources of anthropogenic food may also be a cause for colony desertion.

Summing up the surveys carried out, it should be stated that large parks rich in tree species are appropriate nesting sites for large breeding colonies. Small and degraded parks, with few species of trees, were places where smaller rookeries occurred. Small rookeries located in parks show a tendency to disappear more quickly than the larger ones. Disturbance remains a significant factor responsible for the distribution and size of colonies. If disturbed by humans, small colonies in rural parks are irrevocably abandoned. Large rookeries can remain deserted for several years and then can be reoccupied by birds again. Sources of anthropogenic food remain an important factor influencing the distribution of breeding colonies of rook.

\section{References}

ArcView (1996). The Geographic Information Systems for Everyone. Redlands: Environmental Systems Research Institute (ESRI) Inc.

Biaduń, W. \& Wojciak J. (2005). Rook Corvus frugileus (L., 1758) (in Polish). In J. Wójciak, W. Biaduń, T. Buczek \& M. Piotrowska (Eds.), Atlas of breeding birds of Lublin region (pp. 394-395). Lublin: LTO.

Czarnecka, J. \& Kitowski I. (2010). Seed dispersal by the rook Corvus frugilegus L. in agricultural landscape - mechanisms and ecological importance. Pol. J. Ecol., 58(3), 511-523. 
Czarnecka, J. \& Kitowski I. (2013). Rook spring seed dispersal in the agricultural landscape - frugivory, granivory or accidental transport? Folia Geobot., 48, 55-73. DOI: 10.1007/s12224-012-9134-0

Dolata, P. (2005). Rook Corvus frugilegus w Ostrów Wielkopolski town and district (W Poland) (in Polish). In L. Jerzak, B.P. Kavanagh \& P. Tryjanowski (Eds.), Corvids of Poland (pp. 671-679). Poznań: Bogucki Wyd. Nauk.

Fijałkowski, D. \& Kseniak M. (1982). The rural parks of the Lublin region (in Polish). Warszawa: PWN.

Gromadzka, J. (1980). Food consumption of the rook Corvus frugilegus in agrocoenoses in Poland. Acta Ornith., $17,227-255$.

Grzybek, J. (2004). Nesting of rook Corvus frugilegus at Leżańsk and Nisko districts (in Polish). Ptaki Podkarpacia, $10,75-78$.

Hordowski, J. (2004). Survey of rook's colonies at Jarosław and Przemyśl districts (in Polish). Ptaki Podkarpacia, $10,61-66$.

Hordowski, J. (2009). The rook in the Carpathian Foothills: species monograph and economic Importance. Poland: Bolestraszyce.

Jakubiec, Z. (2005). Rook Corvus frugilegus in Poland - current knowledge and research perspectives (in Polish). In L. Jerzak, B.P. Kavanagh \& P. Tryjanowski (Eds.), Corvids of Poland (pp. 89-111). Poznań: Bogucki Wyd. Nauk.

Kamecki, H. (2004). Nesting of rook rook Corvus frugilegus in south part of Przeworsk district (in Polish). Ptaki Podkarpacia, 10, 75-78.

Kasprzykowski, Z. (2005). Dynamics of breeding population of the rook Corvus frugilegus in the agricultural landscape of eastern Poland in the years 1998-2003 (in Polish). In L. Jerzak, B.P. Kavanagh \& P. Tryjanowski (Eds.), Corvids of Poland (pp. 655-663). Poznań: Bogucki Wyd. Nauk.

Kawa, P. \& Pelc B. (2001). Nesting of rook rook Corvus frugilegus in Rzeszow region (in Polish). Ptaki Podkarpacia, 9, 37-46.

Kujawa, K. \& Klajber K. (2005). Changes in breeding population size of the rook Corvus frugilegus in the General Chłapowski Landscape Park (in Polish). In L. Jerzak, B.P. Kavanagh \& P. Tryjanowski (Eds.), Corvids of Poland (pp. 665-669). Poznań: Bogucki Wyd. Nauk.

Kułak, A. \& Sender J. (2011). Park -and -palace complex as biodiversity refuges on example Galezow ex-manor park. Teka Komisji Ochrony i Kształtowania Środowiska Przyrodniczego, 8, 73-85.

Kuźniak, S., Lorek, G., Maćkowiak, S. \& Kosicki J.Z. (2005). The rook Corvus frugilegus in the Leszno Province (in Polish). In L. Jerzak, B.P. Kavanagh \& P. Tryjanowski (Eds.), Corvids of Poland (pp. 641-654). Poznań: Bogucki Wyd. Nauk.

Neubauer, G., Sikora, A., Chodkiewicz, T., Cenian, Z., Chylarecki, P., Archiwa, B., Betleja, J., Rohde, Z., Wieloch, M.,Woźniak, B., Zieliński, P. \& Zieliński M. (2011). Monitoring of population of Polish birds in 2008-2009 (in Polish). Biuletyn Monitoringu Przyrody, 8, 1-40.

Orłowski, G. \& Czapulak A. (2007). Different extinction risks of the breeding colonies of rook Corvus frugilegus in rural and urban areas of SW Poland. Acta Ornithologica, 42(2), 145-155.

Pietrowiak, J. (2011). Rook Corvus frugilegus in Jarocin Land (Wielkopolska) - status after 35 years (in Polish). Przeglad Przyrodniczy, 22(1), 108-116.

Profus, P., Glowaciński, Z., Marczakowski, P. \& Krogulec J. (1992). Avifauna of the voivodeship of Zamość (in Polish). Studia Ośrodka Dokumentacji Fizjograficznej, 20, 113-208.

Taczanowski, W. (1882). Ptaki krajowe. 1-2. Kraków.

Tobółka, M., Szymański, P., Kuźniak, S., Mackowiak, S., Kaczmarek, S., Maliczak, J., Michalak, W., Ratajczak, J., Sieracki, P. \& Stępniewski J. (2011). Decline of the rook Corvus frugilegus breeding population in the Leszno Province (in Polish). Ornis Polonica, 52, 107-116.

Truchan, M. \& Sobisz Z. (2006). The rural parks of the southern part of Damnica Plateau (in Polish). Stupskie Prace Biologiczne, 3, 101-117.

Tryjanowski, P., Kuźniak, S., Kujawa, K. \& Jerzak L. (2009). Ecology of farmland birds (in Polish). Poznan: Bogucki Wydawnictwo Naukowe.

Żurawlew, P. (2007). Nesting of the rook Corvus frugilegus in the District of Pleszew (Wielkopolska) (in Polish). Przeglad Przyrodniczy, 18(3-4), 117-124. 